University of Louisville

ThinkIR: The University of Louisville's Institutional Repository

Electronic Theses and Dissertations

9-1949

\title{
A thermometer technique for the determination of emissivities of finishes.
}

N. P. Shah 1923-

University of Louisville

Follow this and additional works at: https://ir.library.louisville.edu/etd

Part of the Chemical Engineering Commons

\section{Recommended Citation}

Shah, N. P. 1923-, "A thermometer technique for the determination of emissivities of finishes." (1949).

Electronic Theses and Dissertations. Paper 2164.

https://doi.org/10.18297/etd/2164

This Master's Thesis is brought to you for free and open access by ThinkIR: The University of Louisville's Institutional Repository. It has been accepted for inclusion in Electronic Theses and Dissertations by an authorized administrator of ThinkIR: The University of Louisville's Institutional Repository. This title appears here courtesy of the author, who has retained all other copyrights. For more information, please contact thinkir@louisville.edu. 


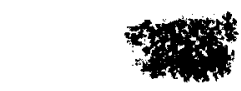

UTIVIRS ITY OF LOU ISV TLEE

A THERMONINTR THCHN IQUE FOR THE DHTIRTIDATION OF WISS IV IT IES OF FIIISHES

\author{
A Thesis \\ Submitted to the Faculty \\ of the Graduate School \\ of the University of Louisville \\ In Partial Fulfillment \\ of the Requirements \\ for the Degree of
}

MASTER OF CLIMICAL WWG DWHER IIV

Department of Chemical Eng ineering

N: P. Shah

September 1949 
This PDF document is a scanned copy of a paper manuscript housed in the University of Louisville (UofL) Libraries. The quality of this reproduction is greatly dependent upon the condition of the original paper copy. Indistinct print and poor quality illustrations are a direct reflection of the quality of materials that are available for scanning. The UofL Libraries greatly appreciates any better copies that can be made available for replacement scans. 
A THIRMOMLTLR TECIDI IUE FOR THE DLTERMATATION OF DW ISS IV IT IES OF FTIISILAS

$$
\text { N. P. Shah }
$$

Approved by the Examining Committee

\begin{tabular}{ll} 
Director $\frac{\text { W. R. Barnes }}{\text { G. C. Williams }}$ \\
$\frac{\text { R. C. Ernst }}{\text { Raymond I. Fields }}$ \\
\hline
\end{tabular}


Page

Iist of Tebles ..................... . iv

Iist. of Figures ..................... iv

Acknowledgment to the Director ............

Abstract ........................ vij

Introduction ...................... 1

Historical ..................... 3

Theoretical ....................... 8

Experimental . . . . . . . . . . . . . . . 21

Summary and Conclusions . . . . . . . . . . 34

Literature Cited . . . . . . . . . . . 36

Appendix . . . . . . . . . . . . . . . 38

Vits ........................ 63 


\section{IIST OF TABLES}

Page

I Jxperimental Rexdings by Dynanic Technique . . 30

II Average Experimental Values of missivities

of Different Finishes by static Technique for

the Temperature Range $70^{\circ} \mathrm{F}$, to $140^{\circ} \mathrm{F} . . . .31$

III Experimental Readings by Static Teohnique . . . 50

\section{LIST OF FIGURES}

1 Diagrammatic sketch of Apparatus showing Temperaturea used in Calculations . . . . . . 10

2 Coefficient of Heat Trensfer by Convection . . 17

3 Sketch of Apparetus . . . . . . . . . . 33

4 Arrangement of Baffles . . . . . . . . . 25

5 Arrangement of Thermometers . . . . . . . 25

6 Density and Thermel Conductivity of Air . . . . 61

7 Specific Leet and Viscosity of Air . . . . . 62 
ACIONOWLEDGMINIT 
The euthor wishes to acknowledge

the kind assistance and holpful guidance

of Dr. W. R. Barnes

who directed this research 
ABETRACT 
Two thermometer techniques for the determination of emisivities of surface coatings aro presented. One procedure involving the attainment of steady state heat transfer relations in coated thermometers placed through the wall of a duct at right angleg to the diroction of air flow was found to give consistent results. Another procedure based upon the rate of change of themometer temperature was found to give consistent results only with excellont control of air conditions.

The emissivities of a variety of paints, vamishes, and lacquers were determined for the temperature range $90^{\circ} \mathrm{F}$. to $140^{\circ}$ F. Uaing silver and black coatings for standardization. The results obtained by means of the static technique were more satiofactory. 
ITTRODUCT ION 
One of the complex problems of heat transmission is the evaluation of radiant-heat transmission or interchange between a ges and its bounding surface or between surfaces separated by a nonabsorbing medium. The temperature at which radiation accounts for a significant amount of the total heat transmission defends on such factors as the emissivity of the surface and the magnitude of the convection coefficient. Early methods appearing in the Iiterature (2) for the determination of the emissivity of different materials were comylicated and required costly equipment. The inprovement and simplification of many processes involving radiation have been desirable, but as in the case of many other heat transmission problems, the lack of data has prevented a rational approach to its solution.

This study was undertaken to obtain emisoivity data of different inishes under the conditions encountered at moderate temperaturea. In addition, a relatively simple thermometer technique was to be investigated. Two methods, one a dynamic procedure and the other a static method, were considered for obtaining the emissivity data of different surfaces and materials. To verify the correctness of the methods, a standard surface of silver whose emissivity was well established, would be suitable standard for evaluating the technique. With the establishment of a suitable experimental procedure, the emissivities of a number of different colored finishes could be selected for investigation. 
H ISTOR ICAL 
The word emissivity (2) comes from the Lat in 'emittere' meaning to send out. In accord with that primery meaning an emissivity for a given material is a measure of the ability of a surface made of that material to send out radiant energy. Such an ability might be expressed in terms of the rate of emission per unit of surface area. Accordingly, there is some use of the word 'emissivity' in this sense. However, general usage of emissivity is as a ratio comparing the ability of a radiating material with that of a perfect emitter, a black body, at the same temperature.

In the interior of an opaque body of uniform temperature throughout, at diatances from its at:rface yielding practically complete absorption for entering radietion, black body conditions are found. If the body is a black body, the rate of emission of radiant energy from its surface will correspond to the unhindered pessage of radiant energy from such an interior. If the body is a non-black body, the rate of enission will be lessened becouse of the hindrance, in the way of reflection occurring at the surface. ith these facts in mind, it is netural to express an erissivity for a nonblack body as a ratio of the sending out ability for an opaque body composed of the non-black material to the corresponding ability for a bleck body at the same temperature.

in accord with the usage that an "lvity" ending shall dente a characteristic of a material, the term "emiasivity" is I imited to a comparision with a black body under 
conditions that the individual cherecteristics of bodies composed of the material under considerction are el iminated. Since the radiating characteristics of a body depend in part upon its opaqueness and the roughness of its surface, these feetures mut be considered in forming an acceptable definition of emissivity. Base of specification and of reproduction are the obvious reasons for requiring that the emissi$\nabla$ ities of materials shall refer to comparisions made with opeque specimens whose surfaces are polished. Accordinely, the emissivity of a meterial is defined as the ratio of a rete of emiasion of radiant energy by an opeque body with polished surface composed of that material as a consequence of its temperature only, to the corresponding rate for 2 blacl body at the same temperature.

Two other terms, nemely emissive power and emission factor, have been and are still used to some extent to indicate what is now meant by emissivity. In accord with the usage that an "ance" ending shall denote a cheracteristic of a body or a portion of a body rather than of the material composing jt, an enittance for a body at some constant temperature is defined as the ratio of emission of radiant energy by the body in consequence of its temperature only to the correaponding rete for a black body at the same temperature. The condition of the surfece of a body, polished or not, and the condition as to opaquenes are immaterial. 
There are various standpoints from which the radisting ability of a non-black body may be considered. The two nost common are the total heating effects per unit area, taking account of all wave-lengths of radiation, and the spectral heating effects, taking account of only a very 1 imited range of wave-lengths. Accordingly total and apectral omissivities are obteined. If the stand-point is one of viaual effects rather than of heating effecta produced by the radiation, a Iuminous or visible emissivity is obtained.

For each of the foregoing types of emissivity, at least two subdivisions are recognized: a normel, and a hemispherical emissivity. The need for this subdivision results from deviations from Iambert's cosine law (2) exhibited by the radiction from non-black bodies.

As the following work deals with themel radiation only, a hemiepherical total emiasivity and a nomal total emissi$\nabla$ ity only are to be considered. Thermal radiation means the quality and quantity of radiant energy emitted per unit time depending solely on the temperature of the given body, referred to merely as radiation rather than by the more descriptive term "thermal radiation".

A hemispherical total emissivity for the poliahed surface of an opeque portion of material at congtant temperature is the ratio of its rediancy to that of black body material at the same temperature. The radiancy of a source of radiation is its rate of emission of radiant energy per unit of area. 
A normel total emissivity for the polished surface of an opaque portion of material at constant temperature is the ratio of its nomal radiancy to that of black body meterial at the same temperature.

A number of different procedures are available for experimentelly determining emissivities (2) involving to a great extent rather special and carefully calibrated apperatus. 
THEORET ICAL 
In the dexivations that follow, the apparatus is assumed to consist of suitable mercury thermometerg in an air stream at right angles to the flow with in an enclosing pipe. Further it is asumed that (a) all heat effects are sensible, 1.e. Iatent heats of reaction are excluded; (b) the temperature throughout the stem of the thermometer and along the cross-section of the duct is essentially uniform; (c) the end area of the thermometer is smell compared to the surface area of the irmersed cylindrical portion of the thermometer; (d) the intensity of radiation is uniforn, a difficult condition to obtain over large areas; and (e) the rate of heat flow between gas and pyrometer by the mechenism of gas radiation, and the heat conducted from the pyrometer to the walls confining the gas stream are negligible.

In the equations developed for the evaluation of emissivities of surface coatings, two different mercury-glass thermouneter techniques were employed. In the first procedure steady state conditions of heat transfer were not obtained, and the process was called a dymamic technique. In the second procedure steady atate conditions of heat transfer were realized and the process was termed a static technique. 


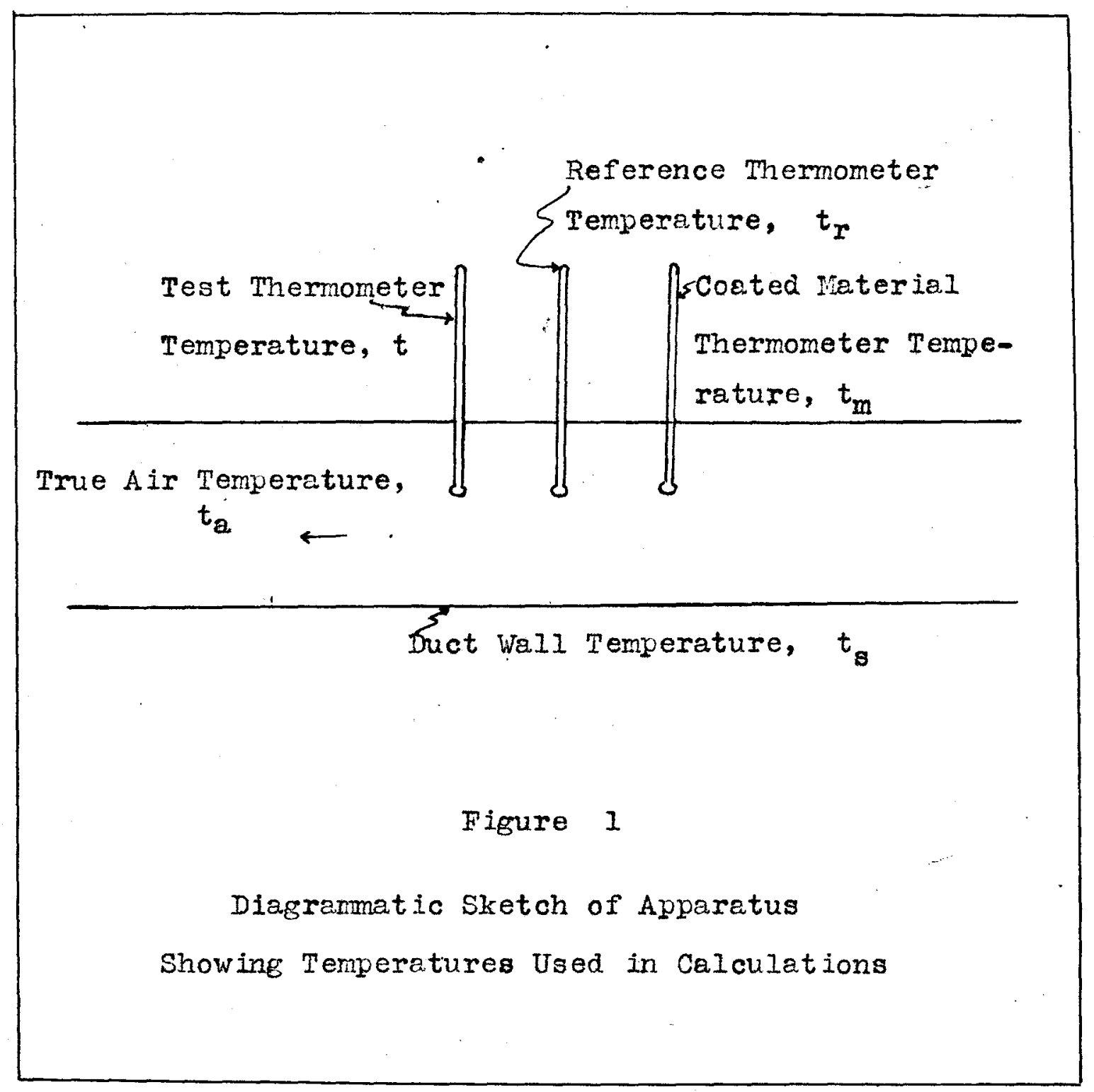


DVIAIIC TECRI IQUE

When a test thermometer, initially at some temperature above or below an air streem temperature, is inserted at right angleg to the flow through a duct wall as shown in Flgure 1, the quantity of heat $d Q$ trangferred to or from the inmersed part of the test thermometer in $t$ ime $d \theta$, can be expressed by the following equation:

$$
d Q=C \rho V d t
$$

where

$$
\begin{aligned}
& C=\text { specific heat of the immersed part of } \\
& \text { the test thermometer, B.t.u./(1b.) }\left({ }^{\circ} s_{*}\right) \\
& p=\text { Density of the immersed part of the test } \\
& \text { thermometer, } 1 \mathrm{~b} . / \mathrm{cu} . \mathrm{ft} \text {. } \\
& V=\text { Volume of the immersed part of the test } \\
& \text { thermometer, cu.ft. } \\
& \text { dt }=\text { Test themoneter temperature change during } \\
& \text { the interval de, degrees } F \text {. }
\end{aligned}
$$

This quentity of heat is carried from or to the thermometer by convection and rediation, ckin be expressed methematically:

$$
d Q / d \theta=h_{c} A\left(t_{a}-t\right)-h_{r} A\left(t-t_{S}\right)
$$

where

$$
\begin{aligned}
A= & \text { Heat transfer area of the immersed part } \\
& \text { of the test themometer, sq.ft. }
\end{aligned}
$$


$h_{0}=$ Coefficient of heat transfer by convec-

tion for test thermometer, B.t.u. per hour per sq.ft. per degree $F$.

$h_{I}=$ Coefficient of heat transfer by radia-

tion for test thermometer, B.t.u. per hour fer sq.ft. per degree $F$.

$t_{B}=$ Temperature of the surface in sight of the thermometer, degree $F$.

$t_{B}=$ True temperature of air, degree $F$.

$t=$ Temperature of the test thermometer.

Using the relation $\left(t-t_{3}\right)=\left(t_{a}-t_{3}\right)-\left(t_{a}-t\right)$, and combining equations (1) and (2), the following relation is obtained:

$$
\begin{aligned}
d Q & =C P V d t \\
& =\left(h_{c}+h_{r}\right) A\left(t_{a}-t\right)-h_{r} A\left(t_{a}-t_{s}\right) d \theta
\end{aligned}
$$

Rearrangement of equation (3) regults in

$$
d \theta=\left[\frac{c \rho v}{A\left(h_{c}+h_{r}\right)}\right]\left[\frac{d t}{\left(t_{a}-t\right)-\frac{h_{r}\left(t_{a}-t_{g}\right)}{h_{c}+h_{r}}}\right]
$$

Integration of equation (4) between the 1 imits $t_{1}$ and $t_{2}$. and corresponding values of $\theta_{1}$ and $\theta_{2}$ results in

$$
\Delta \theta=\frac{c \rho v}{A\left(h_{c}+h_{r}\right)} \text { in }\left[\left(t_{a}-t\right)-\frac{\left(t_{a}-t_{B}\right)}{1+h_{r} / h_{c}}\right]_{t_{1}}
$$


The heat gained by convection in case of a static reference thermometer, identicel in every respect to the previousiy: mentioned test thermometer, Fist equal the heat lost by radiation if the initial assumptions are valid and

$$
q_{c}=q_{r} \text { or } h_{c}^{\prime} A\left(t_{Q}-t_{r}\right)=h_{r}^{A}\left(t_{r}-t_{s}\right)
$$

where $q_{c}=$ Rate of heet flow between gas and thermometer, B.t.u.Arr.

$q_{r}=$ Sum of the verious terms representing the rate of the radiant heat interchange between the thermometer and the various surfeces that it "sees", B.t.u./hr. $h_{c}=$ Coefficient of heat trangfer by convection for reference thermometer, B.t.u. per hour per sq.ft. per degree $F$.

$h_{x}^{\prime}=$ Coefficient of heat transfer by radiation for reference thermometer, B.t.u. per hour per sq.ft. yer degree F.

and $\left(t_{r}-t_{g}\right)=\left(t_{a}-t_{B}\right)-\left(t_{a}-t_{r}\right)$

Therefore, $\quad\left(t_{a}-t_{r}\right)=\left[\frac{h_{r}^{\prime}}{h_{c}^{\prime}+h_{r}^{\prime}}\right]\left(t_{a}-t_{g}\right)$

Since the test thermometer and the reference thermometer are identical in every respect, $h_{c}=h_{c}^{\prime}$ and $h_{r}=h_{r}^{\prime}$ 
Substitution of the value of $\left(t_{a}-t_{r}\right)$ from equation $(6)$ in equation (5) yields

$$
\Delta \theta=\frac{C P V}{A\left(h_{c}+h_{x}\right)} \text { In } \frac{t_{I}-t_{x}}{t_{2}-t_{x}}
$$

For the case in which the test themometer and the coated material thermometer are identical in every respect, for the same cooling time, equation (7) reaults in

$$
\Delta \theta=\frac{c_{1} p_{1} v_{1}}{A_{1}\left(h_{c I}+h_{r I}\right)} \text { in } \frac{t_{1}-t_{m}^{\prime}}{t_{2}^{\prime}-t_{m}^{\prime}}
$$

where $A_{1}=$ Heat transfer area of the immersed part of the coated meterial thermometer, sq. ft.

$V_{1}=$ Volume of the Immersed part of the coated material thermometer, cu.ft.

$P_{1}=$ Density of the immersed part of the coated material thermometer, Ib./cu.ft.

$h_{c l}=$ Coefficient of heat transfer by convection for the coated material themometer, B.t.u. per hour per sq.ft. per degree $F$. $h_{r l}=$ Coefficient of heat transfer by radiation for the coated material thermometer, B.t.u. per hour per sq.ft. per degree F.

$t_{1}$ - Initial temperature of test thermometer, identical with reference thermometer, ${ }^{\circ}$. $t_{2}=$ Final temperature of test thermometer, identical with reference thermometer, ${ }^{\circ} \mathrm{F}$. 
$t_{1}=$ Initial temperature of teat thermometer, identical: with coated material thermometer, ${ }^{\circ} \mathrm{F}$.

$t_{2}^{\prime}=$ Final temperature of test thermometer, Identical with coated material thermometer, ${ }^{\circ} \mathrm{F}$.

$t_{x}=$ Temperature indicated by the reference thermometer, $\circ \mathrm{F}$.

$t_{m}=$ Temperature indicated by the coated material thermometer, $\circ \mathrm{F}$.

An inspection of equations (7) and (8) reveels that all the terms may be evaluated experimentally with the exception of the radition heat transfer coeffioient. The dimensions and properties of the thermometers will permit the evaluation of $\mathrm{C}, \mathrm{C}_{1}, \rho, \rho_{1}, \mathrm{~V}, \mathrm{~V}_{1}, \mathrm{~A}$, and $\mathrm{A}_{1}$. The cooling time for the test thernometer is the value of $\Delta \theta$.

From a knowledge of the air velocity and properties as well as dimensions of the themometers, $h_{c}$ and $h_{c}^{\prime}$ may be evaluated as follows:

From the equations for single cylinders (3) with air flowing at right angles to the cylinder:

$$
h_{c} D_{0} / k_{f}=0.32+0.43\left(D_{0}^{G / u_{f}}\right)^{0.52}
$$

for a Reynolds Number range from 0.1 to 1,000 For single cylinders $(3)$ in the range of $D_{0} G / u_{f}$ from 1,000 to 50,000 the dimensionless equation (10) should be used: 


$$
h_{c} D_{0} / k_{f}=0.26\left(D_{0} G / u_{f}\right)^{0.6}\left(c_{p} u_{f} / k_{f}\right)^{0.3}
$$

For air and diatomic gases $\left(c_{p} u_{f} / k_{f}\right.$ of 0.74$)$, this reduces to

$$
h_{c} D_{0} / k_{f}=0.24\left(D_{0} G / u_{f}\right)^{0.6}
$$

A plot of Reynolds liumber ve $h_{c}$ or eir velocity $v a h_{0}$ can be prepared, and the value of $h_{c}$ read directly from a plot as shown in Flgure 2 .

Then $h_{r}$ and $h_{\dot{r}}$ can be evaluated by solving equations (7) and (8). The heat transferred by radiation is given by the equation

$$
\begin{aligned}
q_{Y} & =h_{Y} A\left(t_{Y}-t_{g}\right) \\
& =0.173 F_{A} F_{B}\left[\left(T_{Y} / 100\right)^{4}-\left(T_{B} / 100\right)^{4}\right]
\end{aligned}
$$

where $F_{A}=$ A geometric factor (3), in this case the heat transfer area of the thermometer, A sq.ft. $F_{\text {IE }}=$ An emissivity factor, in this case that of the thermometer.

$T_{r}=$ Absolute temperature as indicated by the reference thermoneter, ${ }^{\circ} \mathrm{R}$.

$T_{a}=$ Absolute temperature of the surface in sight of the thermometer, ${ }^{\circ} \mathrm{R}$.

For this case equation (12) becomes 


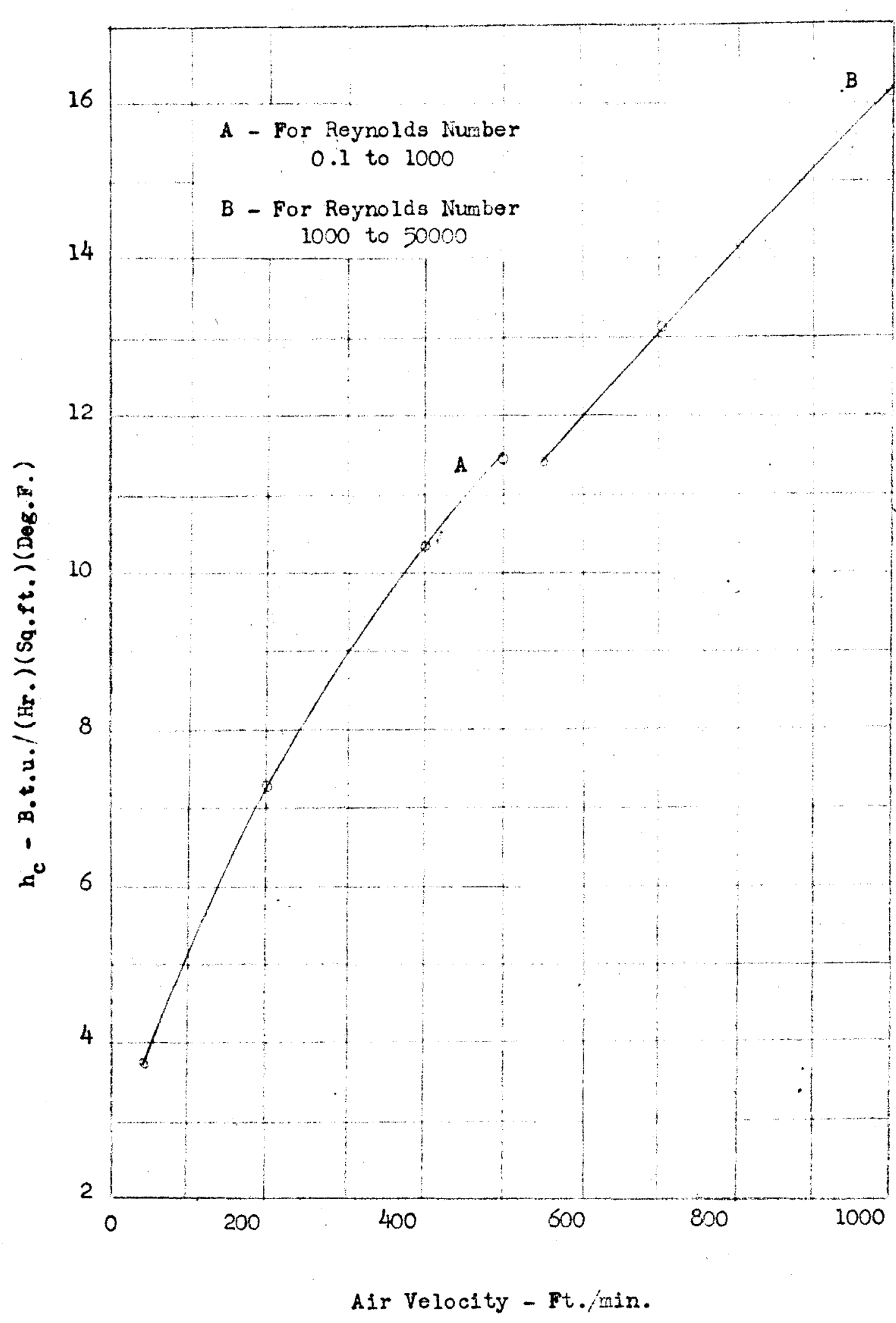

FIG. 2 - COEFFICIENT OF EAAT TRALUFER BY COINECTIOH 


$$
h_{Y} A\left(t_{X}-t_{B}\right)=0.173 A G_{Y}\left[\left(T_{Y} / 100\right)^{4}-\left(T_{B} / 100\right)^{4}\right]
$$

and $G_{m}$ may be computed for the coated material thermometer by substituting $h_{r l}$ for $h_{r}, T_{m}$ for $T_{r}$, $t_{m}$ for $t_{r}$ and $G_{m}$ for $G_{x}$ in equation (13), where the subscript $m$ refers to the coated material thermometer.

\section{STATIC TECHEIOUUE}

In the derivation of the theoretical relations for the static procedure, essentially the same apparatus as shown in the diagramatic sketch of Figure I is employed. The thermometer technique is varied somewhat in that all thermometers are allowed to attain constant readings in the air stream.

For using the dynomic procedure the true temperaturs of the air stream was not required, but in the static procedure the true air temperature must be eveluated. To compute the true temperature of a gas at moderate temperatures from the reading of a themoneter placed in a gea stream and in aight of surrounding walls that may be at temperatures difierent from that of the gas, an approximate heat balance for the thermometer may be used:

$$
q_{c}=q_{r}
$$

where $q_{c}=$ Rate of heat flow between gas and thermometer by convection, B.t.u./hr. 


$$
\begin{aligned}
& q_{x}= \text { Sum of the various terms representing the } \\
& \text { rate of radiant heat interchange between } \\
& \text { the thermometer and the various surfaces } \\
& \text { that it "sees", evaluated by equation (12) } \\
& \text { B.t.u. per hour. }
\end{aligned}
$$

In the imple case of an ir stream having a true temperature $t_{e}$ and flowing through a duot of a diameter large compared to that of a reference thermometer at temperature $t_{r}$, the inner surfeces of the wells having approximetely constant temperature $t_{\beta}$, a heat belenoe on the thermometer gives the equation

$$
q_{c}=q_{r} \text { or } h_{c} A\left(t_{a}-t_{r}\right)=h_{r} A\left(t_{r}-t_{s}\right)
$$

where the air temperature $t_{a}$ is sbove that of the thermometer $t_{\boldsymbol{x}}$ and the surface of the duct $t_{\mathrm{g}}$. Equation (14) may be written in the form

$$
h_{c} A\left(t_{a}-t_{r}\right)=0.173 a_{A} A\left[\left(T_{r} / 100\right)^{4}-\left(T_{s} / 100\right)^{4}\right]
$$

also, equation (14) may be rearranged to

$$
\left(t_{a}-t_{r}\right)=\left(h_{r} / h_{c}\right)\left(t_{x}-t_{s}\right)
$$

Similaxly for the coated material thermometer equetion (16) may be applied:

$$
\left(t_{e}-t_{m}\right)=\left(h_{x l} / h_{c l}\right)\left(t_{m}-t_{s}\right)
$$


Under the same conditions $h_{c}=h_{c l}$, for the thermometers of the same size equation (27) becomes

$$
\left(t_{a}-t_{m}\right)=\left(h_{r 1} / h_{c}\right)\left(t_{m}-t_{s}\right)
$$

The value of $h_{c}$ can be determined from the air velocity, thermometer oimensions, and air properties by means of equations (9) and (11) or read directly from the air velocity vo. $h_{c}$ chart (Fig. 2). The ralue of $h_{x}$ can be obtained from equation (13). Fnowing all other terms, $t_{a}$ can be evaluated from equation (16). Substituting the velue of $t_{a}$ in equation (18), $h_{x l}$ is obtained. Then using the velue of $h_{r l}$ and substituting $h_{r l}$ for $h_{r}, T_{m}$ for $T_{r}$, $t_{m}$ for $t_{r}$ and $\sigma_{m}$ for $c_{r}$ in equation (13), the emissivity of the material in question can be determined. 
IXXPHR IIMTSI 
In this atudy one object was the development of a satisfactory thermometer technique for the determination of enissivities of surface coatings. Another object was the evaluation of the enissivities of a variety of aurface coatings using the thermometer teahnique. To these ends experiments were carried out using the two different themometer techniques to select the more setisfactory procedure.

\section{APPARITUS}

The epparatus used in this researah was essentially a long duct 8 inches in diameter through whoh heated ir was passed, Suitable openings permitted the placement of thermometers in the air stream. The apparatus is shown diagrammatically in Figure 1 and in more pletorial resesentation in Figure 3.

Two different heat sources, one a compartment dryer and the other an electrical resistance heater, were used for heating the air. In the compartment dryer, air was drawn through a fan and then orer steam tubes. Steam was regulated by means of a reducing valve in the steam line and by a manually operated valve on the dryer, which in turn controlled the flow of steam and subsequently the temperature of the air. Finaliy, the heated air was passed through the exhaust duct, the test apparatus of this study.

When electrical heaters were used, air was draw directly over heated resistance wire, the blower, and then passed 


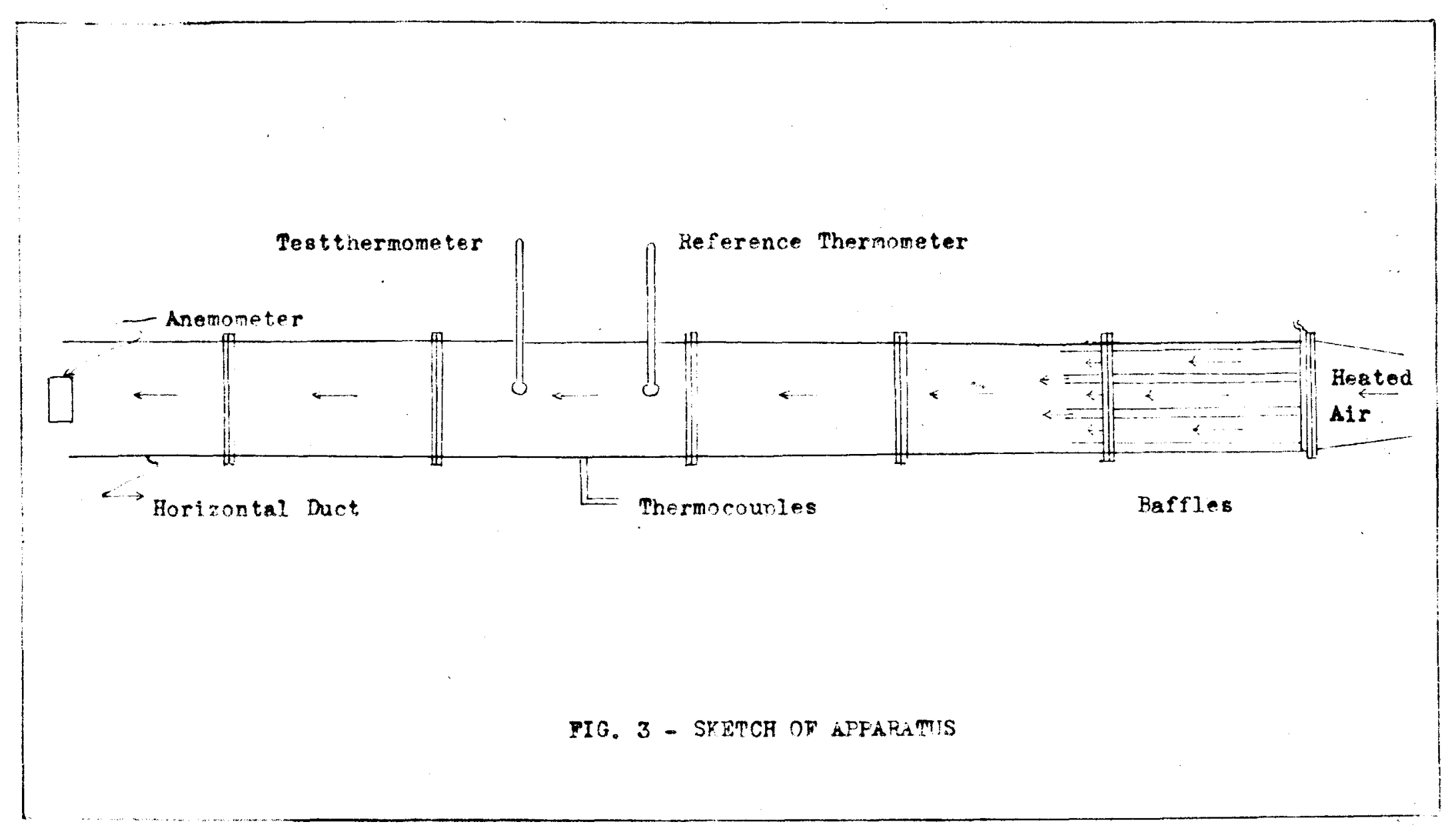


through a duct of the seme dimensions as above.

In order to regulate air velocity, two altermately slotted discs of the seme cross-section as the duot, were installed at $r i g h t$ angles to the flow of air. One disc was permanently fixed, and the other was free to rotate for controling the eir velocity.

A number of tubular atraighteners were installed as shown in Figure 4 to obtain a unfform temperature distribution throughout the cross-section of the duct. Three insertions (Fig. 5), one for thermocouples to measure the wall temperature of the duct, and the other two for thermometers, were made at one station in the duct about 90 degrees from each other and at a sufficient distance from the exit of the duct and from the baffles to give uniform temperatures and black body conditions.

A potentiometer was used to measure the wall temperature of the duct as indicated by copper-constantan themocouples. Two mercury-glass thermometers, celibreted to one tenth degree centigrade, were used as reference and material themometers.

\section{PROCIDUTRES}

In order to test the theory, it was necessary to have values of emissivities of the standird selected surfaces, the coefficients of heet transfer, physical properties (4) of the finiah under exanination, and temperature-time data. 

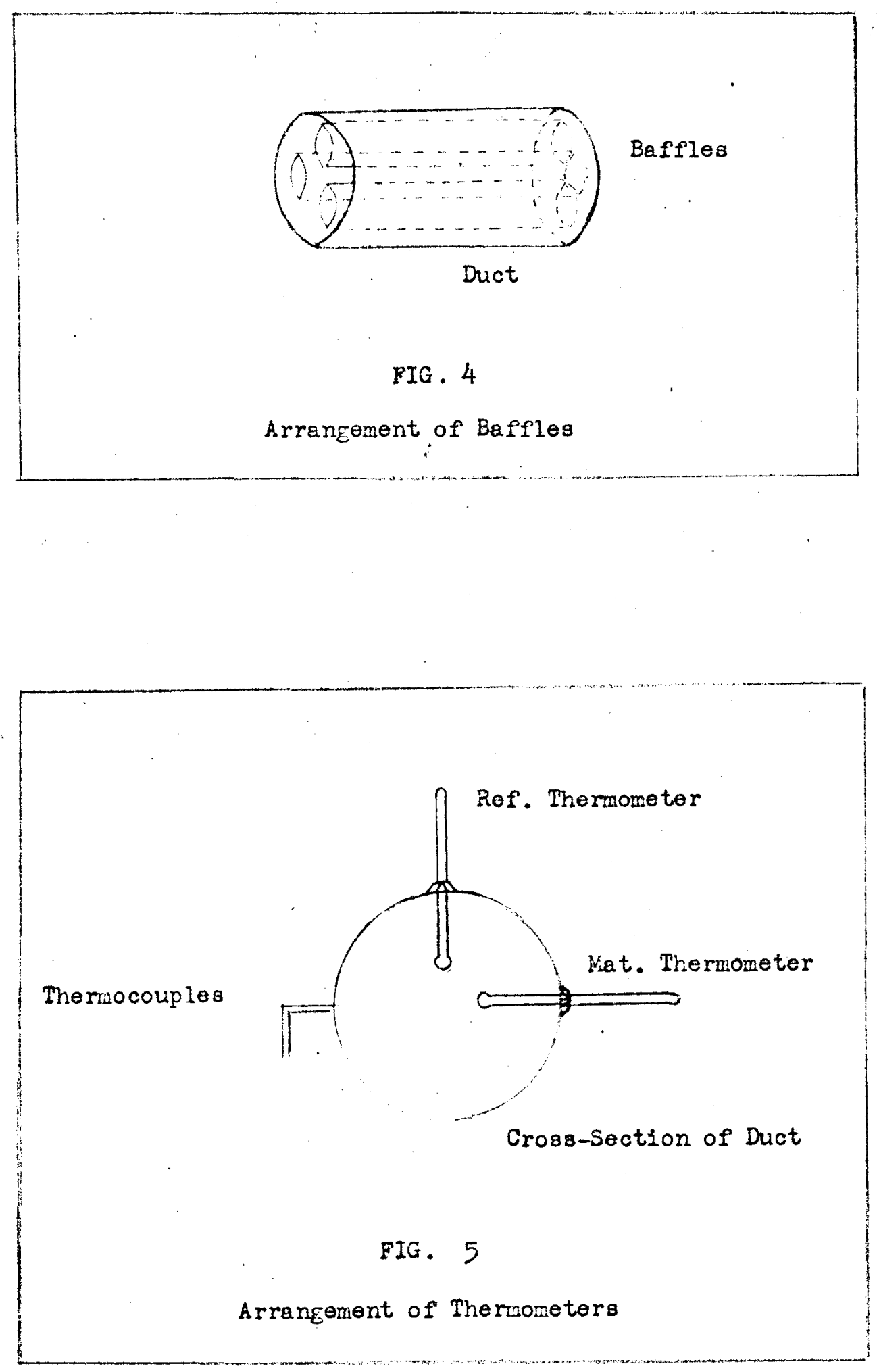
For a very accurte recording of the true temperature of air by means of the reference thermometer, the surface of the reference thermometer should have low radiction characteristics. In other words, this surface should have a very low emissivity, which is true for a well polished silver surface. To obtain low emissivities the test and the reference thermometers were coated with silver by Braghear's method (5). The material themometer was coated with the different iniahes by means of a camel's heir brugh, so that the final diameters of a.l the thermometers remained very nearly the same.

As the temperature distribution elong the cross-section of the duct was found to be non-uniform, three points et equal distances from the insertions through the wall of the duct were selected, and a correction factor was obtained for each point; and each thermometer reading was corrected accordingly. This procedure in turn fixed a constant and equal length of Immersion for all thermometers through the openings. However, a constent and equel surface erea for all thermometers was degirable to minimize the celculetions inrolved in determining the final value of enissivity.

The relocity of air was measured at different pointb along the cross-soction of the duct by means of an anemometer, and the finel value wa determined by averaging all readings. nowing the diameters and heet transfer areas of the thermometers, the heat transfer coefficient was computed by means of equations (9) and (11). 


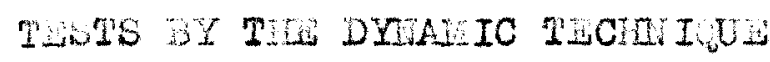

The air was passed over the steam or the electrical colls and adjusted to the desired air velocity and eir temperature. The reference and the coated naterial themometers were installed in the air atream through openings $A$ and $B$ of Fig. 5 where they were left for a auficient period to obtain an accurate and steady temperature reading. rhe test thermometer was then placed in a beaker of hot water so that it registered some temperature considerably above the temperature of the ir stream. It was removed from the hot water, wiped $\mathrm{dry}$, and placed in the air current several inches from the reference thermoneter in such fishion that the axis of the bulb was at right angles to the flow of the air. The time required for the temperature indicated by the test themometer to fall some reviously selected number of degrees was recorded. This time, and the temperature reedines of the test, the material, and the reference thermometers alone with the vall temperature of the duct were recorded. The air velocity was measured by neans of an anemometer; and the finel value of the emissivity of the material on the meterisl thermometer was computed by equations $(8),(11)$ and (13).

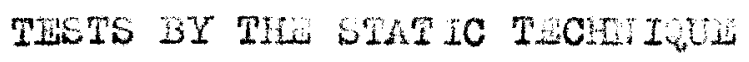

In the static method, all steps were followed exactly in the same manner as above; however, the changing temyerature 
recdings and time intervals were not required. In other words, the temperature readings of the reference and the material thermometers, the temperature of the wall of the duct, and the air velocity were recorded. The value of the emissivity was computed by equations (9), (11), (15), (16) and $(18)$.

COAT IIGS

For reference purposes a silver coating was aplied to one of the thermometers used in thege experiments. An additional reference coting lamp-black also was used. Six differently plgmented peints were used as experimental coatings. Compositions of these peints are given in the Appendix.

\section{RESULS}

Although the dynamic themometer procodure was used in a number of emissivity determinetions, the extreme care necesaery in adjusting air conditions and temperatures makes this procedure more difficult to use and, in general, less satisfuctory than the static procedure. In Table I are show typical deta and emissivity values obtained using the dynamic technique.

In Table II are itemized the average experimental values obtained using the static technique. The complete data for the coatings are presented in Table III in the Appendix. 
Limissity valueg were found to vary from 0.575 for yellow paints to 0.954 for a mercury in glass thermometer or lamp black coating. 
TABLE I Bxperimental Readings by Dynamic Technique

Run $t_{m} \quad t_{\mathrm{g}} \quad t_{1} \quad t_{2}$ time velo- emisNo. $\operatorname{deg} . F \operatorname{deg} . F \quad \operatorname{deg} . F$ deg.F secs. $\mathrm{ft} / \mathrm{min}$

Material: Silver

\begin{tabular}{lllllllll}
\hline 1 & 132.35 & 118.00 & 149.00 & 140.00 & 26.30 & 990 & 0.0203 \\
2 & 132.80 & 118.00 & 149.00 & 140.00 & 27.40 & 900 & 0.0203 \\
3 & 133.34 & 119.00 & 140.00 & 140.00 & 28.70 & 990 & 0.0201 \\
4 & 134.22 & 119.00 & 158.00 & 149.00 & 15.95 & 990 & 0.0201 \\
\hline
\end{tabular}

Waterial: Glass-Mercury Thermometer

\begin{tabular}{|c|c|c|c|c|c|c|c|}
\hline 1 & 134.60 & 122.00 & 158.00 & 149.00 & 15.00 & 1025 & 0.9380 \\
\hline 2 & 135.14 & 122.00 & 158.00 & 149.00 & 15.15 & 1025 & 0.9490 \\
\hline 3 & 134.96 & 122.00 & 158.00 & 149.00 & 15.20 & 1025 & 0.9480 \\
\hline \multicolumn{8}{|c|}{ Material: Lamp-Black } \\
\hline 1 & 136.58 & 123.00 & 158.00 & 149.00 & 17.50 & 925 & 0.5540 \\
\hline 2 & 136.76 & 123.00 & 158.00 & 149.00 & 17.80 & 925 & 0.9550 \\
\hline 3 & 136.94 & 123.00 & 158.00 & 149.00 & 17.40 & 925 & 0.9540 \\
\hline 4 & 137.12 & 123.00 & 158.00 & 149.00 & 17.95 & 925 & 0.9560 \\
\hline
\end{tabular}

All other data necessary to compute emissivities of different inishes and materials are presented in the Sample Calculations of this Thesis. 
TABLE II Average Experimental Values of lamissivities of Different Finishes by Static Method for the Temperature Range $90^{\circ} \mathrm{F}$. to $140^{\circ} \mathrm{F}$.

Symbol Finish Emissivity

\begin{tabular}{rll}
\hline- & Glass-Mercury Themometer & 0.954 \\
- & Iamp-Black & 0.954 \\
$Y$ & Yellow & 0.375 \\
0 & Orenge & 0.855 \\
R & Red & 0.815 \\
$G$ & Green & 0.779 \\
PB & Dhthalocyanine & 0.934 \\
MB & Milori Blue & 0.825 \\
\hline
\end{tabular}




\section{DISCUSSION}

Both thermoneter techniques for the determination of emissivities of different materials were besed on the consideration that the rate of transfer of energy by radiation between two surfaces was a function of the normal total enissivities. Hence, it wes essential that ex erimental readings be obtained with the thermometers aensitive enough to indicete the radiant energy variations realized with the verious coating materials.

One of the favorable features of the dynamic thermometer technique for the evaluation of emissivities of surface coatings wes that no reference coetings were required. The technique mey be employed merely using two themometers in an air stream of known velocity. In addition, the temperature of the surfece in sight of the themometers wes required although an accurete value of the true air temperature was unnecessary. The procedure was satigfetory when air stream irregularities were at a minimum. Iowever, when velocity and temperature fluctuations were present, the procedure was unreliable.

When the stetic procedure was used, elthough a widely fluctuating air stream was undesirable, minor variations could be tolerated. However, with this procedure a reference coating was necessary, and a.11 results in effect were compered with the emissivity velue of the reference coating. 
In addition, it was necessary to evaluate the true temperature of the air stream. Nevertheless, the stat ic procedure was found to givethe more consistant results primarily because sI ight veriations in the alr stream could be tolerated.

With reasonable precautions and the relatively simple equiment required for these procedures it was felt that quite accurate emissirity values could be established for non-black body coating materials. 
SUTMARY AND CONCLUS IONS 
As a result of this study of themometer techniques in the determination of emissivities of surface coatings several conclusions were obteined. In general, it was found that the stetic technique gave the more setiafactory results primarily because of the tolerence of minor ar stream fluctuations. Wevertheless, the dynamic technique geve setisfectory results when a sufficiently uniform air streani was obtoinable.

For non-transparent surface coating the themometer technique for evalueting emissivities were considered sufficiently accurate for most ong ineering calculations requiring informetion of this neture. 
IITIRATURE CITED 
(1) Bermes, W.R., Speed Scientific School, University of Louisville, Kentucky. Information on test thermometer (Frivate Communication) 1949

(2) Worthing, A. G., "Temperature, its Messurement and Control in Science and Industry", pp. 1164-86, New York, Reinold Publishing Corporation, 1946

(3) MaAams, W. H., "Heat Transmission" 2nd edition, pp. 220-24, 391,406. Hew York, McGraw Hill Book Company, Inc. 1946

(4) Villiams, G. C., Head Chemical Ingineering Department, University of Louisville, Louigville, Kentucky. Information on finishes (Private Communication) 1949

(5) Hodgman, Charles D., "Hand Book of Chemistry and Physics" 3oth edition, pp. 2537-39. Cleveland, Chernical Rubber Publishing Company, 1948 


\section{APFERTIX}


A Heat trensfer area of the immersed part of the reference thermorneter, sq.ft.

$A_{1}$ Heat transfer area of the immersed part of the coated material thermometer, sq.ft.

C Specific heat of the inmersed part of the reference thermometex, B.t.u./(1b.) (deg.F.)

$C_{1}$ Specific heat of the imrerged part of the coated material thermometer, B.t.u./(Ib.)(deg. F.)

$C_{p}$ Specific heat of air at constant pressure of $760 \mathrm{~m} . \mathrm{m}$. of $\mathrm{Hg} ., \mathrm{B}_{\text {.t.u. }} /\left(\mathrm{Ib}_{\bullet}\right)\left(\mathrm{deg} \cdot \mathrm{F}_{*}\right)$

$D_{0}$ Diameter of themoneter, $f t$.

h Coefficient of heat transfer, B,t.u, per hour per sq.ft. per deg. F.

$h_{c}$ Coefficlent of heet txansfer by convection for test thermometer, B.t.u./(hr.)(sq.ft.)( deg. $\mathrm{F}$.

$h_{c}^{\prime}$ Coefficient of heat transfer by convection for reference thermorneter, B.t.u./(hr.)(sq.ft.) (deg. F.)

$h_{01}$ Coefficlent of heat transfer by convection for coated materiel themoneter, B.t.u./(hr.)(sq.ft.)(deg.F.)

$h_{x}$ Coefficient of heat transfer by radiation for test thermometer, B.t.u./(hr.)(sq.ft.)(deg.F.)

hi Coefficient of heat trangfer by radiation for reference thermometer, B.t.u./(hr.) (sq.ft.)(deg.F.) 
$k_{f}$ Thermel conductivity of air, B.t.u./(hr.)(sq.ft.) $(\mathrm{OI} / \mathrm{ft})$

Q quantity of heat transferred, B.t.u.

$q$ Rate of heet transfer, B.t.u.hr.; $q_{c}$ and $q_{r}$ are defined on page 13.

$t$ Temperature, degree $F_{0} ; t_{\varepsilon}$ true tempercture of air; $t_{r}$ temperature recorded by the reference thermometer; $t_{m}$ temperature recorded by coated meterial themoneter.

$t_{1}$ Initial temperature of test themometer, identical with reference themometer, deg. F.

$t_{2}$ Hinal temperature of test thermometer, identical with reference thermometer, deg. F.

$t_{i}$ Initial temperature of test themometer, identical with coated material thermoneter, deg. F.

$t_{2}^{\prime}$ Final temperature of test thermometer, identical with coated material thermometer, deg. $I$.

$V$ Volume of immersed part of reference thermometer,cu.ft.

$V_{1}$ Volume of imersed part of coated material thermometer, cu.ft.

$\checkmark$ Velocity of air, ft./hr.

$\leftrightarrow$ Missivity, Gr emigsivity of the meterial on the reference thermometer; $6 \mathrm{~m}$ emissivity of the finish on the material thermometer.

$\rho$ Density of the immersed pert of the reference thermometer Ib./cu.ft. 
$P_{1}$ Density of the immersed pert of the costed material thermometer, $1 b . / c u . f t$.

$\rho^{\prime}$ Density of air, 1b./cu.ft.

- Tine in hours.

9 Time in seconds. 


\section{SAITLE CALCULATIONS}

TABLE I Jxerimental Readings by Dymamic Technique Material: Lamp-BIack, fun Ho.?

Deta:

$t_{m}, \operatorname{deg}$. F. . . . . . . . . . . . .

136.76

$t_{3}, \operatorname{deg} . \xi_{.} . . . . . . . . . . . .$.

123.00

$t_{I}$, deg. F..

158.00

$t_{2}, \operatorname{deg} . \mathrm{F}$.

149.00

$0_{1}$, in seconds ..............

17.80

Velocity of eir, ft./min.

925.00

$D_{0}$ of all thermometers, ft.

0.02196

$k_{f}$ of air, B.t.u. per hour wer sq.ft. per

deg. F./ft.; between 130 to $160 \mathrm{deg}$. F. . . .

0.0166 $e^{\prime}$, density of air, Ib./cu.ft. ....... 0.0660

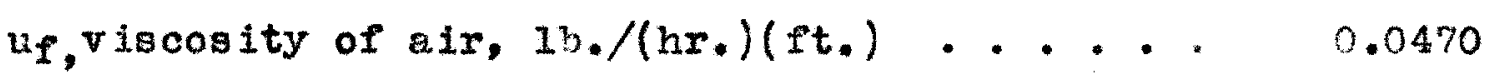
$c_{p}$, specific heat of air, $B_{*} t_{\cdot} u_{*} /\left(\mathrm{Ib}_{*}\right)\left(\mathrm{O}_{\mathrm{E}}\right)$

0.2530

$V=v_{1}$, volume of immersed part of the thermo-

meter, cu.ft. ................... $D_{O}^{2} / 4 \mathrm{I}$

Length of immersion of all thermometers,ft. . . I

$A=A_{1}$, heat transfer area of the themoneter, sq.ft. .................

$D_{0} L$

$\rho=\rho_{1}$, density of the immersed part of the

thermometer, 1b./cu.ft. . . . . . . (2.24)(62.4) 
$c=C_{1}$, specific heat of the immersed part of the thermometer, B.t.u./(I $\mathrm{B})\left(\mathrm{O}_{\mathrm{F}}\right)$....... 0.194

Evaluation of $h_{c}$ or $h_{c l}$ :

$$
\begin{aligned}
\text { Reynolds Rumber } & =D_{0} \nabla e^{\prime} / u_{f} \\
& =(0.02196)(0.066)(55,500) /(0.047) \\
& =1714
\end{aligned}
$$

Therefore, substitution in equetion (17) gives:

$$
\begin{aligned}
h_{c I} & =(0.26)\left(k_{f} / D_{0}\right)\left(c_{p} u_{f} / k_{f}\right)^{0.3}\left(D_{0} G / u_{f}\right)^{0.6} \\
& =(0.26)(0.756)(0.905)(1714)^{0.6} \\
& =(0.1775)(87.10) \\
& =(15.425) \quad \text { B.t.u. } /\left(h_{r}\right)(\mathrm{sq.ft.})\left(\mathrm{og}_{f}\right)
\end{aligned}
$$

ivaluation of constant $C P V / A O$ in equation (10):

$$
\begin{aligned}
C_{P} V / A \theta & =\frac{C \rho\left(D_{0}^{2} / 4\right) L}{D_{0} L\left(O_{1} / 3600\right)} \\
& =(900)(C)(\rho)\left(D_{0}\right) / \theta_{1} \\
& =(900)(0.194)(140)(0.02196) / \theta_{1} \\
& =535 / \theta_{1} \text { B.t.u. } /(\mathrm{hr} .)(\text { sq.ft. })\left(\mathrm{og}_{0}\right)
\end{aligned}
$$

Substitution in equation (10) gires

$$
\begin{aligned}
h_{c}+h_{r 1} & =535 / 0_{1} \text { In }\left(t_{1}-t_{m}\right) /\left(t_{2}-t_{m}\right) \\
& =535 / 17.8 \text { In }(158.00-136.76) /(149.0-136.76) \\
& =(30.7)(0.5508)=16.78 \text { B.t.u. } /(\mathrm{hr} .)\left(\mathrm{sq} . \mathrm{ft}_{\bullet}\right)\left({ }^{\circ} \mathrm{F} \cdot\right)
\end{aligned}
$$


Therefore, $\quad h_{I I}=\left(h_{I I}+h_{c l}\right)-\left(h_{c l}\right)$

$=(16.78-15.425)$

$=1.355$ B.t.u. $/\left(h_{0}\right)\left(s q_{\bullet} f_{0}\right)\left(0 \mathrm{~F}_{\bullet}\right)$

Changing the subscript $r$ to $m$ and substituting $h_{r l}$ for $h_{r}$ in equation (13), $5 \mathrm{~m}$ could be expressed in the following form:

$$
\begin{aligned}
\sigma_{m} & =\frac{h_{r 1}\left(t_{m}-t_{s}\right)}{0.173\left[\frac{\left.\left(T_{m} / 100\right)-\left(T_{s} / 100\right)^{4}\right]}{4}\right.} \\
& =\frac{(1.355)(136.76-123.00)}{(0.173)\left[(5.9676)^{4}-(5.83)^{4}\right]} \\
& =(1.355)(13.76) /(0.173)(1268.3-1155.3) \\
& =(1.355)(13.76) /(0.173)(113.00) \\
& =0.955
\end{aligned}
$$

TABLE II Experimental Readings by static Technique

Naterial : Lamp-Black, Run No. 3

Data:

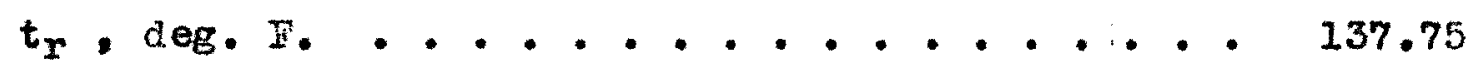

$t_{m}$, deg. F. . . . . . . . . . . 136.58

$t_{s}$, deg. F. .............. 123.00

Velocity of air, ft./min. ......... 920.00 
At air velocity of $920 \mathrm{ft.} / \mathrm{min}$. ;

$$
h_{c}=h_{c l}=15.42 \text { B.t.u. } /\left(h_{*}\right)(\text { sq.ft. })\left({ }^{\circ} F_{*}\right)
$$

Us ing equation (15), and relotion

$$
h_{r}\left(t_{r}-t_{g}\right)=0.173 \quad c_{r}\left|\left(T_{r} / 100\right)^{4}-\left(T_{g} / 100\right)^{4}\right|
$$

where $s \mathbf{r}$ and $t_{r}$ readings were obtained with a silver coated reference thermometer, and the value of the emissivity of silver is teken 0.02 (Table I).

$$
\begin{aligned}
t_{a} & =\frac{0.173 \cdot r\left|\left(T_{r} / 100\right)^{4}-\left(T_{s} / 100\right)^{4}\right|}{h_{0}}+t_{x} \\
& =\frac{(0.173)(0.02)\left|(5.9775)^{4}-(5.83)^{4}\right|}{15.42}+137.750_{F} \\
& =(0.000223)(1275.3-1155.3)+137.75 \\
& =(0.026+137.75) \quad o_{F} \\
& =137.77 \quad \text { deg. F. }
\end{aligned}
$$

Equation (18) can be written as:

$$
\begin{aligned}
\sigma_{m} & =\frac{h_{c}\left(t_{a}-t_{m}\right)}{0.173\left|\left(T_{m} / 100\right)^{4}-\left(T_{g} / 100\right)^{4}\right|} \\
& =(15.42)(137.77-136.58) / 0.173(5.9658)-(5.83)^{4} \\
& =(15.42)(1.19) /(0.173)(1266.6-1155.3) \\
& =(15.42)(1.19) /(0.173)(111.3) \\
& =0.955
\end{aligned}
$$


Information on Different Finishes (4)

Composition of Color Paints

The vehicle for all the colors 100 the sane, namely, Glyptal 12504 reduced with mineral spirits to $50 \% \mathrm{n}$. V. and naphthenate driers and Jational Aniline Anti-skin Agent added as follows: $0.075 \%$ Cobalt, $0.5 \%$ Lead and $0.4 \%$ Anti-Skin Agent, based on the non-volatile. Viscosity of above F-G. Constants on GIyptal the 2504

Constents of Solution

SoIids Content - weight $59-61 \%$

Solvent - Petroleum Spirits

Viscosity (G.I.)

$\mathrm{U}-\mathrm{W}$

Color (Gardner)

8 Mex.

Acid No. of solution

$4-6$

Pounds per gellon

7.7

Resin Solids Constants

Phthalic Anhydride

$24 \%$

Ros in or derivetives

None

Phenolic Resins

None

oil acids content

$60 \%$

Type of 011

Soya 
Information on Different Finishes (continued)

\begin{tabular}{|c|c|c|c|c|}
\hline $3-\mathrm{Pb}-1$ & -4 & oz. & Eulu Blue & per gel. Vehicle \\
\hline $1-P B-2$ & -6.5 & oz. & Ti-lure $\mathrm{n}-610$ & per gal. Vehicle \\
\hline $2 B-1$ & $\begin{array}{r}4 \\
-\quad 8\end{array}$ & $\begin{array}{l}\text { oz. } 4845 \\
\text { oz. }\end{array}$ & $\begin{array}{l}\text { Zulu Blue } \\
\text { Ti-Pure R-610 }\end{array}$ & $\begin{array}{l}\text { yer gal. Vehicle } \\
\text { per gel. Vehicle }\end{array}$ \\
\hline $1-P B-1$ & -4 & oz. 4845 & Zulu Blue & per gal. Vehicle \\
\hline $1-P 3-2$ & -5 & $o z$ & Ti-Pure R-610 & per gal. Vehicle \\
\hline $1-2 B-1$ & -4 & oz. 4845 & Sulú slue & per gel. Venicle \\
\hline $3-P B-2$ & -3.5 & oz. & Ti-rure $R-610$ & per gal. Vehicle \\
\hline$P B-2$ & $\begin{array}{r}4 \\
-\quad 3\end{array}$ & $\begin{array}{l}\text { oz. } 48845 \\
o z .\end{array}$ & $\begin{array}{l}\text { Zulu Blue } \\
\text { Ti-Pure R-610 }\end{array}$ & $\begin{array}{l}\text { per ge.l. Vehicle } \\
\text { yer gel. Vehicle }\end{array}$ \\
\hline
\end{tabular}

Ti-fure R-610 is gotile non-chelking titenium dioxide.

Nilori Blues (Iron ilues - 1 iOn)

\begin{tabular}{|c|c|c|c|c|c|}
\hline $3-1$ & & $\begin{array}{l}4 \\
8\end{array}$ & $\begin{array}{l}\text { oz. } 4022 \\
\text { oz. }\end{array}$ & $\begin{array}{l}\text { Milori BIue } \\
\text { Ti-Ture R-610 }\end{array}$ & $\begin{array}{l}\text { per gel. Vehicle } \\
\text { per gal. Vehicle }\end{array}$ \\
\hline$-103-1$ & & 4 & oz. 34023 & Milori Blue & 1. \\
\hline$-N B-2$ & 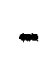 & 6.5 & $a z$. & Ti-Pure R-610 & per ÉI. \\
\hline$-2 B-1$ & - & 4 & oz. 4022 & Milori BIue & a. \\
\hline $1-\operatorname{lng} 3-2$ & - & 5 & oz. & Ti-Pure R-6 & per gal. \\
\hline$-M \mathbb{B B}-1$ & - & 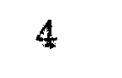 & oz. 4022 & Milori Blue & yer gel. Veh \\
\hline$-203-2$ & 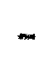 & 3.5 & oz. & Ti-Ture R-610 & per gel. Veh \\
\hline $\mathrm{B}-2$ & & $\begin{array}{l}4 \\
2\end{array}$ & $\begin{array}{l}\text { oz. } 4022 \\
\text { oz. }\end{array}$ & $\begin{array}{l}\text { Milori Blue } \\
\text { Ti-Pure R-610 }\end{array}$ & $\begin{array}{l}\text { ex gal. Vehi } \\
\text { er gal. Vehi }\end{array}$ \\
\hline
\end{tabular}


Infornation on Different Finishes(continued)

Reds

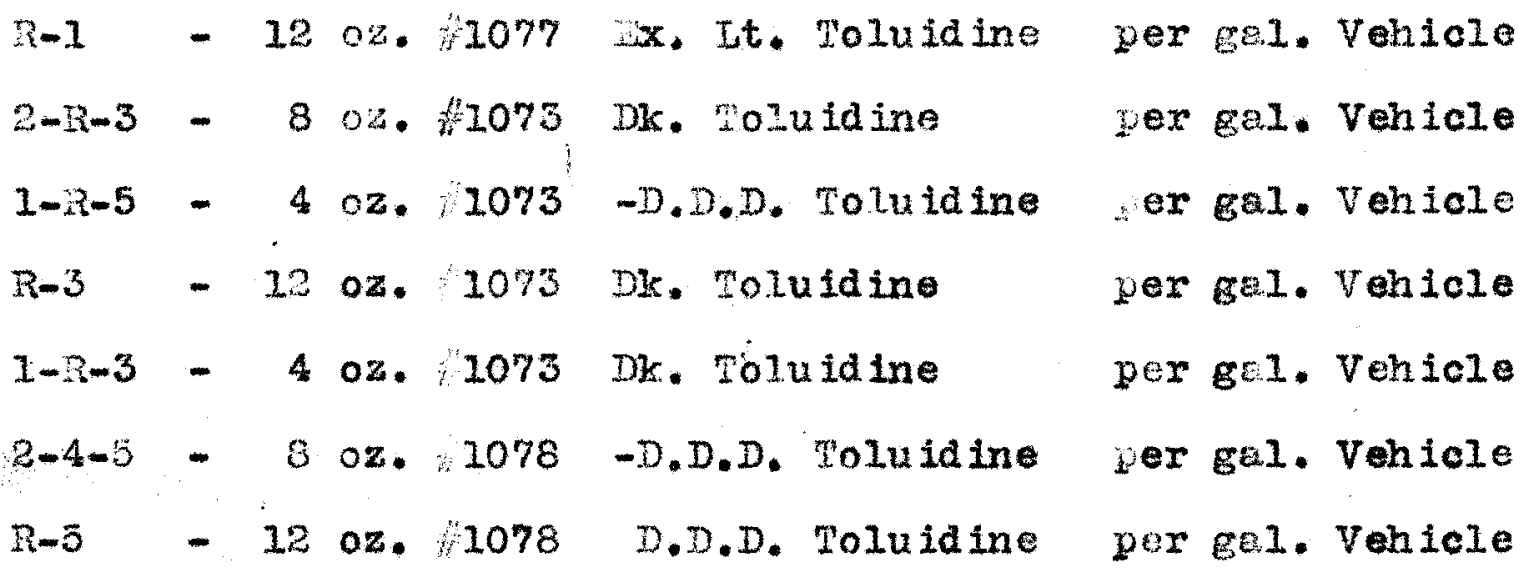

Greens (Chrome Green)

\begin{tabular}{|c|c|c|c|c|}
\hline$G-1$ & -16 & oz. 8405 & Lt. Creen & per gel.Venicle \\
\hline$G-2$ & -16 & oz. 8410 & Med.Green & per gel.Vehtcle \\
\hline $2-G-2$ & $-\quad 10.67$ & ox. 13410 & Med.Green & per gal.vehicle \\
\hline $1=G=5$ & 5.33 & oz. 8425 & Dk. Green & per gel.Vehicle \\
\hline $1-G-2$ & 5.33 & oz. 8410 & Med.Green & per gal.Vehicle \\
\hline $2-G-3$ & $-\quad 10.07$ & oz. 8425 & DK. Green & per gel.Vehicle \\
\hline$G-3$ & $-\quad 16$ & oz. 8425 & Dk. Green & per gel.Vehicle \\
\hline
\end{tabular}




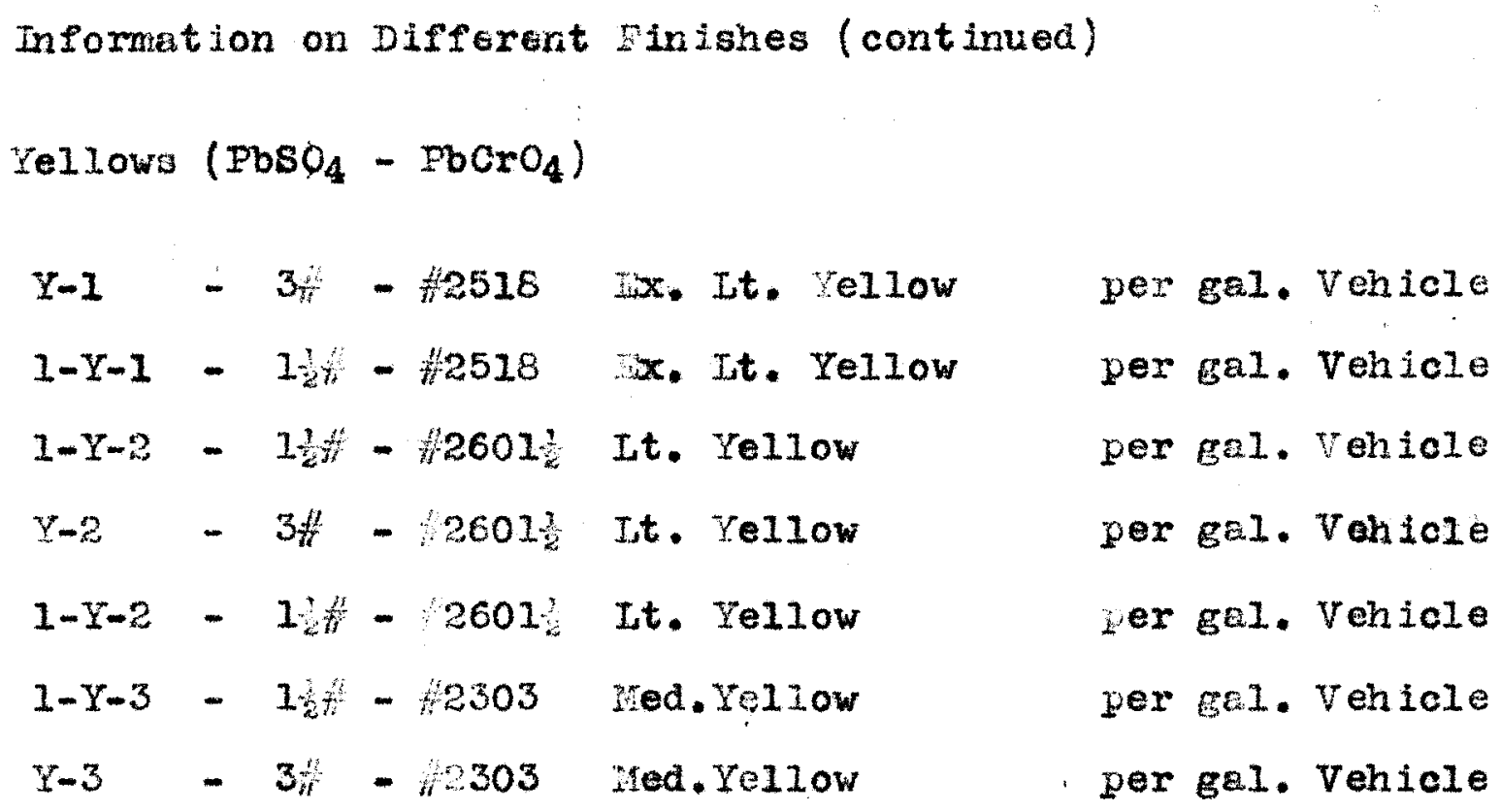

Oranges $\left(\mathrm{PbCrO}_{4}\right)$

0-1 - 3- $-\$ 2604$ It. Yellow per gal. Vehicle $1-0-1-1 \frac{1}{2} 2604$ Lt. Orange per gal. Vehicle 1-0-2 - 1 0-2 - 3t - 2213 red. orange per gel. Vehicle $0-3-3 \#-7209$ Dk. On ne per gel, vehicle 0-4 - 3\% - waso6 Dark Orange per gal. Venicle 
TABLI III Experimental Readings by static Technique

\begin{tabular}{|c|c|c|c|c|c|}
\hline $\begin{array}{l}\text { Run } \\
\text { No. }\end{array}$ & $\begin{array}{c}* t_{x} \\
\operatorname{deg} \cdot F\end{array}$ & $\begin{array}{c}t_{m} \\
\operatorname{deg} \cdot F\end{array}$ & $\begin{array}{c}t_{\mathbf{g}} \\
\mathrm{d} \in \mathrm{g} . F\end{array}$ & $\begin{array}{l}\text { velo- } \\
\text { city } \\
\text { ft/min }\end{array}$ & $\begin{array}{l}\text { enis- } \\
\text { sivity }\end{array}$ \\
\hline & Seterial: & \multicolumn{4}{|c|}{ Gless-Piercury Thermometer } \\
\hline 1 & 134.60 & 133.88 & 122.00 & 990 & 0.949 \\
\hline 2 & 135.32 & 134.60 & 125.00 & 990 & 0.950 \\
\hline 3 & 135.32 & 134.24 & 121.00 & 975 & 0.955 \\
\hline 4 & 135.14 & 134.06 & 121.00 & 975 & 0.957 \\
\hline 5 & 134.60 & 133.52 & 121.00 & 975 & 0.958 \\
\hline \multicolumn{6}{|c|}{ Material: } \\
\hline 1 & 136.94 & 136.04 & 123.00 & 920 & 0.954 \\
\hline 2 & 337.12 & 136.22 & 123.00 & 920 & 0.955 \\
\hline 3 & 137.48 & 136.58 & 123.00 & 920 & 0.954 \\
\hline
\end{tabular}

*t readings were obtained with a silver coated reference thermometer.

All other data necessery to compute emissivities of different finishes and materials are presented in the Sample Calculations of this Theris. 
TABLE III Experimental Reedings by static Technique (continued)

\begin{tabular}{|c|c|c|c|c|c|}
\hline $\begin{array}{l}\text { Run } \\
\text { No. }\end{array}$ & $\begin{array}{c}* t_{r} \\
d e g . F\end{array}$ & $\begin{array}{c}t_{m} \\
\operatorname{deg}_{\cdot} \mathrm{F}\end{array}$ & $\begin{array}{c}t_{g} \\
\operatorname{deg}, \mathrm{F}\end{array}$ & $\begin{array}{l}\text { velo- } \\
\text { city } \\
\text { et } / \mathrm{min}\end{array}$ & $\begin{array}{l}\text { emis- } \\
\text { sivity }\end{array}$ \\
\hline & & Finish: & $R-1$ & & \\
\hline 1 & 140.72 & 140.00 & 118.00 & 490 & 0.299 \\
\hline 2 & 140.90 & 140.18 & 118.00 & 490 & 0.305 \\
\hline 3 & 141.08 & 140.36 & 118.00 & 490 & 0.304 \\
\hline \multirow[t]{2}{*}{4} & $141 \cdot 26$ & 140.54 & 118.00 & 490 & 0.298 \\
\hline & & Fin1sh: & $\mathrm{R}-3$ & & \\
\hline 1 & 132.98 & 132.08 & 119.00 & 916 & 0.785 \\
\hline 2 & 133.34 & 132.44 & 119.00 & 960 & 0.787 \\
\hline 3 & 133.70 & 132.80 & 119.00 & 1000 & 0.784 \\
\hline \multirow[t]{2}{*}{4} & 129.20 & 128.30 & 119.00 & 430 & 0.788 \\
\hline & & Fin ish: & $R-5$ & & \\
\hline 1 & 134.78 & 133.88 & 121.00 & 975 & 0.820 \\
\hline 2 & 134.96 & 134.06 & 121.00 & 975 & 0.868 \\
\hline 3 & 132.80 & 131.90 & 121.00 & 975 & 0.875 \\
\hline 4 & 129.20 & 128.60 & 120.00 & 975 & 0.865 \\
\hline
\end{tabular}


TABLE III Bxperimental Readings by Static Technique (continued)

\begin{tabular}{|c|c|c|c|c|c|}
\hline $\begin{array}{l}\text { Run } \\
\text { No. }\end{array}$ & $\begin{array}{c}* t_{r} \\
\operatorname{deg} . F\end{array}$ & $\begin{array}{c}t_{m} \\
\operatorname{deg} \cdot F\end{array}$ & $\begin{array}{c}t_{8} \\
\mathrm{deg} \cdot F\end{array}$ & $\begin{array}{l}\text { velo- } \\
\text { city } \\
\mathrm{ft} / \mathrm{min}\end{array}$ & $\begin{array}{l}\text { emis- } \\
\text { sivity }\end{array}$ \\
\hline & & Finish & $\begin{array}{l}1-R-3 \\
2-R-5\end{array}$ & & \\
\hline$I$ & 133.52 & 132.80 & 120.00 & 1240 & 0.765 \\
\hline 2 & 131.71 & 131.00 & 120.00 & 940 & 0.768 \\
\hline 3 & 129.92 & 120.20 & 120.00 & 700 & 0.769 \\
\hline \multirow[t]{2}{*}{4} & 128.12 & 127.40 & 120.00 & 405 & 0.763 \\
\hline & & Finish: & $\begin{array}{l}2-R-3 \\
1-R-5\end{array}$ & & \\
\hline 1 & 131.54 & 130.82 & 119.00 & 975 & 0.734 \\
\hline 2 & 132.26 & 131.54 & 119.00 & 1085 & 0.738 \\
\hline 3 & 129.20 & 128.48 & 119.00 & 680 & 0.739 \\
\hline \multirow[t]{2}{*}{4} & 125.60 & 124.88 & 119.00 & 235 & 0.735 \\
\hline & & Finish: & $Y-1$ & & \\
\hline 1 & 147.92 & 147.56 & 144.00 & 310 & 0.625 \\
\hline 2 & 148.18 & 147.92 & 144.50 & 310 & 0.626 \\
\hline 3 & 148.82 & 148.46 & 145.00 & 310 & 0.628 \\
\hline 4 & 149.08 & 148.82 & 146.00 & 310 & 0.629 \\
\hline
\end{tabular}


TABL III Experimental Readings by static Technique (continued)

\begin{tabular}{|c|c|c|c|c|c|}
\hline $\begin{array}{l}\text { Run } \\
\text { No. }\end{array}$ & $\begin{array}{l}* t_{I} \\
\operatorname{deg} \cdot F\end{array}$ & $\begin{array}{c}t_{m} \\
\operatorname{deg} \cdot F\end{array}$ & $\begin{array}{c}t_{8} \\
\operatorname{deg} \cdot F\end{array}$ & $\begin{array}{l}\text { velo- } \\
\text { city } \\
\text { ft/min }\end{array}$ & $\begin{array}{l}\text { emis- } \\
\text { sivity }\end{array}$ \\
\hline & & Fintsh: & $Y-2$ & & \\
\hline$I$ & 144.68 & 144.32 & 141.00 & 310 & 0.660 \\
\hline 2 & 145.06 & 144.86 & 143.00 & 310 & 0.661 \\
\hline 3 & 145.40 & 145.22 & 143.00 & 310 & 0.659 \\
\hline 4 & 147.20 & 146.93 & 144.00 & 310 & 0.660 \\
\hline 5 & 147.92 & 147.56 & 144.00 & 310 & 0.662 \\
\hline
\end{tabular}

Iinish: $\quad \mathrm{Y}-3$

\begin{tabular}{llllll}
\hline 1 & 130.28 & 129.92 & 114.50 & 295 & 0.320 \\
2 & 130.46 & 130.10 & 116.00 & 295 & 0.317 \\
3 & 130.82 & 130.46 & 122.00 & 295 & 0.325 \\
4 & 131.54 & 131.18 & 123.00 & 295 & 0.315 \\
\hline & & Finish: & $1-Y-1$ \\
1 & 138.74 & 138.20 & 120.00 & 490 & 0.342 \\
2 & 138.20 & 137.66 & 120.00 & 490 & 0.345 \\
3 & 137.48 & 136.94 & 120.00 & 490 & 0.344 \\
4 & 137.94 & 137.48 & 120.00 & 490 & 0.343 \\
\hline
\end{tabular}


TABLE III Experimental Readings by Static Technique (continued)

\begin{tabular}{|c|c|c|c|c|c|}
\hline $\begin{array}{l}\text { Run } \\
\text { No. }\end{array}$ & $\begin{array}{c}* t_{r} \\
\operatorname{deg} \cdot F\end{array}$ & $\begin{array}{c}t_{m} \\
\operatorname{deg} \cdot F\end{array}$ & $\begin{array}{c}t_{8} \\
\operatorname{deg} \cdot F\end{array}$ & $\begin{array}{l}\text { velo- } \\
\text { city } \\
\mathrm{ft} / \mathrm{min}\end{array}$ & $\begin{array}{l}\text { emis- } \\
\text { sivity }\end{array}$ \\
\hline & & Finish: & $\begin{array}{l}1-Y-2 \\
1-Y-3\end{array}$ & & \\
\hline 1 & 134.24 & 133.88 & 126.00 & 285 & 0.349 \\
\hline 2 & 134.42 & 134.06 & 126.50 & 285 & 0.348 \\
\hline 3 & 134.60 & 134.24 & 127.00 & 285 & 0.350 \\
\hline 4 & 134.78 & 134.42 & 128.00 & 285 & 0.349 \\
\hline 5 & 135.32 & 134.96 & 128.00 & 285 & 0.351 \\
\hline
\end{tabular}

Finish: $\quad M B-1$

\begin{tabular}{llllll}
\hline 1 & 131.36 & 130.46 & 119.00 & 935 & 0.892 \\
2 & 127.40 & 126.50 & 119.00 & 375 & 0.894 \\
3 & 129.20 & 128.30 & 119.00 & 655 & 0.898 \\
4 & 130.64 & 129.38 & 118.00 & 385 & 0.891 \\
\hline & & $13 i s h$ & $11 \mathrm{BB}-2$ & & \\
\hline 1 & 140.00 & 139.10 & 126.00 & 1225 & 0.899 \\
3 & 139.82 & 138.92 & 126.00 & 1185 & 0.895 \\
4 & 139.64 & 138.74 & 126.00 & 1170 & 0.896 \\
\hline
\end{tabular}


TABLi III ixperimental Readings by static Technique (cont inued)

\begin{tabular}{|c|c|c|c|c|c|}
\hline $\begin{array}{l}\text { Run } \\
\text { No. }\end{array}$ & $\begin{array}{c}t_{\mathbf{r}} \\
\operatorname{deg} \cdot \mathbf{F}\end{array}$ & $\begin{array}{c}t_{m} \\
\operatorname{deg} \cdot F\end{array}$ & $\begin{array}{c}t_{3} \\
\operatorname{deg} \cdot E\end{array}$ & $\begin{array}{l}\text { velo- } \\
\text { city } \\
\text { ft/min }\end{array}$ & $\begin{array}{l}\text { emis- } \\
\text { sivity }\end{array}$ \\
\hline & & Pinish: & $\begin{array}{l}3-M B-1 \\
1-M B-2\end{array}$ & & \\
\hline 1 & 140.00 & 138.74 & 126.00 & 680 & 0.702 \\
\hline 2 & 139.82 & 138.56 & 126.00 & 665 & 0.703 \\
\hline 3 & 140.18 & 138.92 & 126.00 & 700 & 0.705 \\
\hline \multirow[t]{2}{*}{4} & 140.54 & 139.28 & 126.00 & 740 & 0.707 \\
\hline & & Finigh: & $\begin{array}{l}1-M B-1 \\
3-M B-2\end{array}$ & & \\
\hline 1 & 131.00 & 130.10 & 119.00 & 870 & 0.973 \\
\hline 2 & 131.60 & 130.46 & 129.00 & 925 & 0.975 \\
\hline 3 & 129.20 & 128.30 & 119.00 & 650 & 0.982 \\
\hline \multirow[t]{2}{*}{4} & $12 \% .40$ & 126.50 & 219.00 & 375 & 0.974 \\
\hline & & Tinish: & $P B-1$ & & \\
\hline 1 & 124.34 & 123.62 & 114.00 & 970 & 0.890 \\
\hline 2 & 126.59 & 125.78 & 114.00 & 970 & 0.887 \\
\hline 3 & 131.90 & 131.00 & 118.00 & 970 & 0.888 \\
\hline 4 & 130.10 & 129.20 & 117.00 & 970 & 0.891 \\
\hline
\end{tabular}


TABID III Experimental Readings by Static Technique (continued)

\begin{tabular}{|c|c|c|c|c|c|}
\hline $\begin{array}{l}\text { Run } \\
\text { Mo. }\end{array}$ & $\begin{array}{c}* t_{x} \\
\operatorname{deg}_{*} w\end{array}$ & $\begin{array}{c}t_{m} \\
\operatorname{deg} \cdot \mathbf{F}\end{array}$ & $\begin{array}{c}t_{\mathfrak{g}} \\
\operatorname{deg} \cdot \mathrm{F}\end{array}$ & $\begin{array}{l}\text { velo- } \\
\text { city } \\
\text { et/min }\end{array}$ & $\begin{array}{r}\text { emis- } \\
\text { sivity }\end{array}$ \\
\hline & & Finish: & $\begin{array}{l}1-103-1 \\
3-1 M B-2\end{array}$ & & \\
\hline 1 & 245.04 & 143.96 & 130.00 & 1220 & $0.9 \geq 0$ \\
\hline 2 & 145.40 & 244.14 & 130.00 & 980 & 0.908 \\
\hline 3 & 145.76 & 144.50 & 130.00 & 1020 & 0.907 \\
\hline 4 & 146.12 & 144.86 & 130.00 & 1070 & 0.905 \\
\hline \multirow[t]{2}{*}{5} & 144.32 & 143.06 & 130.00 & 865 & 0.905 \\
\hline & & Finish: & $D B+2$ & & \\
\hline 1 & 132.62 & 131.72 & $12 \mathrm{C} .00$ & 975 & 0.938 \\
\hline 2 & 132.00 & 131.90 & 120.00 & 975 & 0.939 \\
\hline 3 & 131.00 & 130.10 & 119.00 & 975 & 0.937 \\
\hline \multirow[t]{2}{*}{4} & 127.10 & 126.50 & 119.00 & 975 & 0.940 \\
\hline & & Finiah: & $\frac{1-P B-1}{1-P B-2}$ & & \\
\hline 1 & 133.52 & 132.62 & 120.00 & 1060 & 0.915 \\
\hline 2 & 131.72 & 130.82 & 120.00 & 830 & 0.925 \\
\hline 3 & 129.92 & 129.02 & 120.00 & 585 & 0.920 \\
\hline 4 & 128.12 & 127.12 & 120.00 & 340 & 0.918 \\
\hline
\end{tabular}


TABTE III Hoperimental Readings by static Technique (continued)

\begin{tabular}{|c|c|c|c|c|c|}
\hline $\begin{array}{l}\text { Run } \\
\text { No. }\end{array}$ & $\begin{array}{c}* t_{I} \\
\operatorname{deg} \cdot F\end{array}$ & $\begin{array}{c}t_{m} \\
d e g\end{array}$ & $\begin{array}{c}t_{g} \\
\operatorname{deg} \cdot F\end{array}$ & $\begin{array}{l}\text { velo- } \\
\text { city } \\
\text { ft/min }\end{array}$ & $\begin{array}{l}\text { emis- } \\
\text { ivity }\end{array}$ \\
\hline & & Minjah: & $\begin{array}{l}3-P B-1 \\
1-P B-2\end{array}$ & & \\
\hline 1 & 132.26 & 131.18 & 120.00 & 695 & 0.910 \\
\hline 2 & 133.16 & 132.08 & 120.00 & 695 & 0.315 \\
\hline \multirow[t]{2}{*}{3} & 232.80 & 131.72 & 120.00 & 695 & 0.920 \\
\hline & & Fint.sh: & $\frac{7-P B-1}{3-P B-2}$ & & \\
\hline 1 & 127.58 & 126.86 & 117.00 & 975 & 0.896 \\
\hline 2 & 129.02 & 128.30 & 117.00 & 975 & 0.894 \\
\hline 3 & 125.42 & 124.88 & 117.00 & 975 & 0.898 \\
\hline \multirow[t]{2}{*}{4} & 129.92 & 129.20 & 117.00 & 975 & 0.895 \\
\hline & & Fin 1sh: & $0-1$ & & \\
\hline 1 & 130.55 & 130.10 & 122.00 & 285 & 0.331 \\
\hline 2 & 130.28 & 129.92 & 122.00 & 285 & 0.321 \\
\hline 3 & 129.83 & 129.26 & 121.50 & 285 & 0.342 \\
\hline
\end{tabular}


TABIE III Experimental Readings by stetic Teahnique ( continued)

\begin{tabular}{|c|c|c|c|c|c|}
\hline $\begin{array}{l}\text { Run } \\
\text { No. }\end{array}$ & $\begin{array}{c}\operatorname{teg}_{2} \\
F\end{array}$ & $\begin{array}{c}t_{m} \\
a e g \cdot F\end{array}$ & $\begin{array}{c}t_{\mathrm{B}} \\
\operatorname{deg} \cdot \mathrm{t}\end{array}$ & $\begin{array}{l}\text { velo- } \\
\text { city } \\
\text { ft/min }\end{array}$ & $\begin{array}{l}\text { emis } \\
\text { sivity }\end{array}$ \\
\hline & & Fin 1sh: & $0-2$ & & \\
\hline 1 & 154.58 & 154.04 & 148.00 & 310 & 0.5376 \\
\hline 2 & 154.76 & 154.22 & 148.50 & 310 & 0.5925 \\
\hline 3 & 154.94 & 154.40 & 149.00 & 310 & 0.5970 \\
\hline \multirow[t]{2}{*}{4} & 155.14 & 154.58 & 149.20 & 310 & 0.6220 \\
\hline & & Finish: & $0-3$ & & \\
\hline 1 & 136.40 & 136.04 & 132.50 & 315 & 0.6625 \\
\hline 2 & 138.55 & 138.20 & 135.00 & 315 & 0.7214 \\
\hline 3 & 139.46 & 159.10 & 136.00 & 315 & 0.7404 \\
\hline \multirow[t]{2}{*}{4} & 140.72 & 140.36 & 137.00 & 315 & 0.6813 \\
\hline & & In 153 & $9-4$ & & \\
\hline 1 & 148.64 & 148.28 & 145.00 & 310 & 0.640 \\
\hline 2 & 149.00 & 148.64 & 145.00 & 310 & 0.639 \\
\hline 3 & 149.18 & 148.82 & 145.00 & 310 & 0.636 \\
\hline 4 & 149.72 & 149.18 & 144.50 & 310 & 0.637 \\
\hline 5 & 149.72 & 149.36 & 145.00 & 310 & 0.638 \\
\hline
\end{tabular}


TABLE III ixperimental Reeding by static Technique (continued)

\begin{tabular}{|c|c|c|c|c|c|}
\hline $\begin{array}{l}\text { Run } \\
\text { No. }\end{array}$ & $\begin{array}{c}* t_{\mathbf{r}} \\
\operatorname{deg} . F\end{array}$ & $\begin{array}{c}t_{m} \\
\operatorname{deg} \cdot w\end{array}$ & $\begin{array}{c}t_{\mathrm{g}} \\
\operatorname{deg} \cdot \mathrm{F}\end{array}$ & $\begin{array}{l}\text { velo- } \\
\text { city } \\
\text { ft } / \text { min }\end{array}$ & $\begin{array}{l}\text { enis- } \\
\text { sivity }\end{array}$ \\
\hline & & Tinish: & $\begin{array}{l}1-0-1 \\
1-0-2\end{array}$ & & \\
\hline 1 & 140.00 & 139.64 & 136.50 & 315 & 0.6880 \\
\hline 2 & 140.53 & 140.18 & 136.80 & 315 & 0.6705 \\
\hline \multirow[t]{2}{*}{3} & 140.90 & 140.54 & 137.00 & 315 & 0.6437 \\
\hline & & Finish: & $G-1$ & & \\
\hline 1 & 134.96 & 134.60 & 126.00 & 1570 & 0.655 \\
\hline 2 & 134.78 & 134.42 & 126.00 & 1475 & 0.658 \\
\hline 3 & 134.60 & 234.24 & 126.00 & 1420 & 0.659 \\
\hline \multirow[t]{2}{*}{4} & 134.06 & 133.70 & 126.00 & 1260 & 0.656 \\
\hline & & Finish: & $G-?$ & & \\
\hline 1 & 127.94 & 127.04 & 119.00 & 315 & 0.755 \\
\hline 2 & 129.38 & 128.48 & 119.00 & 440 & 0.757 \\
\hline 3 & 129.92 & 129.02 & 126.00 & 45 & 0.759 \\
\hline 4 & 130.28 & 129.38 & 126.00 & 55 & 0.754 \\
\hline
\end{tabular}


TABLE III Experimental Readings by Static Technique (cont inued)

\begin{tabular}{|c|c|c|c|c|c|}
\hline $\begin{array}{l}\text { Run } \\
\text { No. }\end{array}$ & $\begin{array}{c}{ }^{*} t_{\mathbf{r}} \\
\operatorname{deg} \cdot F\end{array}$ & $\begin{array}{c}t_{\mathrm{ma}} \\
\mathrm{deg}=F\end{array}$ & $\begin{array}{c}t_{B} \\
\operatorname{deg} \cdot F\end{array}$ & $\begin{array}{l}\text { velo- } \\
\text { city } \\
\text { ft/min }\end{array}$ & $\begin{array}{l}\text { emis- } \\
\text { sivity }\end{array}$ \\
\hline & & Finish: & $G-3$ & & \\
\hline 1 & 127.04 & 126.32 & 219.00 & 405 & 0.778 \\
\hline 2 & 130.28 & 129.38 & 119.00 & 600 & 0.775 \\
\hline 3 & 132.08 & 131.18 & 119.00 & 805 & 0.779 \\
\hline \multirow[t]{2}{*}{4} & 133.88 & 132.98 & 119.00 & 1010 & 0.776 \\
\hline & & Finish: & $\begin{array}{l}1-G-2 \\
2-G-3\end{array}$ & & \\
\hline 1 & 132.62 & 131.50 & 126.00 & 290 & 0.764 \\
\hline 2 & 131.00 & 130.10 & 126.00 & 90 & 0.765 \\
\hline 3 & 129.20 & 128.30 & 119.00 & 440 & 0.766 \\
\hline \multirow[t]{2}{*}{4} & 127.40 & 120.50 & 119.00 & 285 & 0.768 \\
\hline & & Finish: & $\begin{array}{l}2-G-2 \\
1-G-3\end{array}$ & & \\
\hline 1 & 131.54 & 130.64 & 126.00 & 165 & 0.765 \\
\hline 2 & 132.08 & 131.36 & 126.00 & 300 & 0.766 \\
\hline 3 & 132.44 & 131.72 & 126.00 & 325 & 0.769 \\
\hline 4 & 132.80 & 132.08 & 126.00 & 375 & 0.764 \\
\hline
\end{tabular}




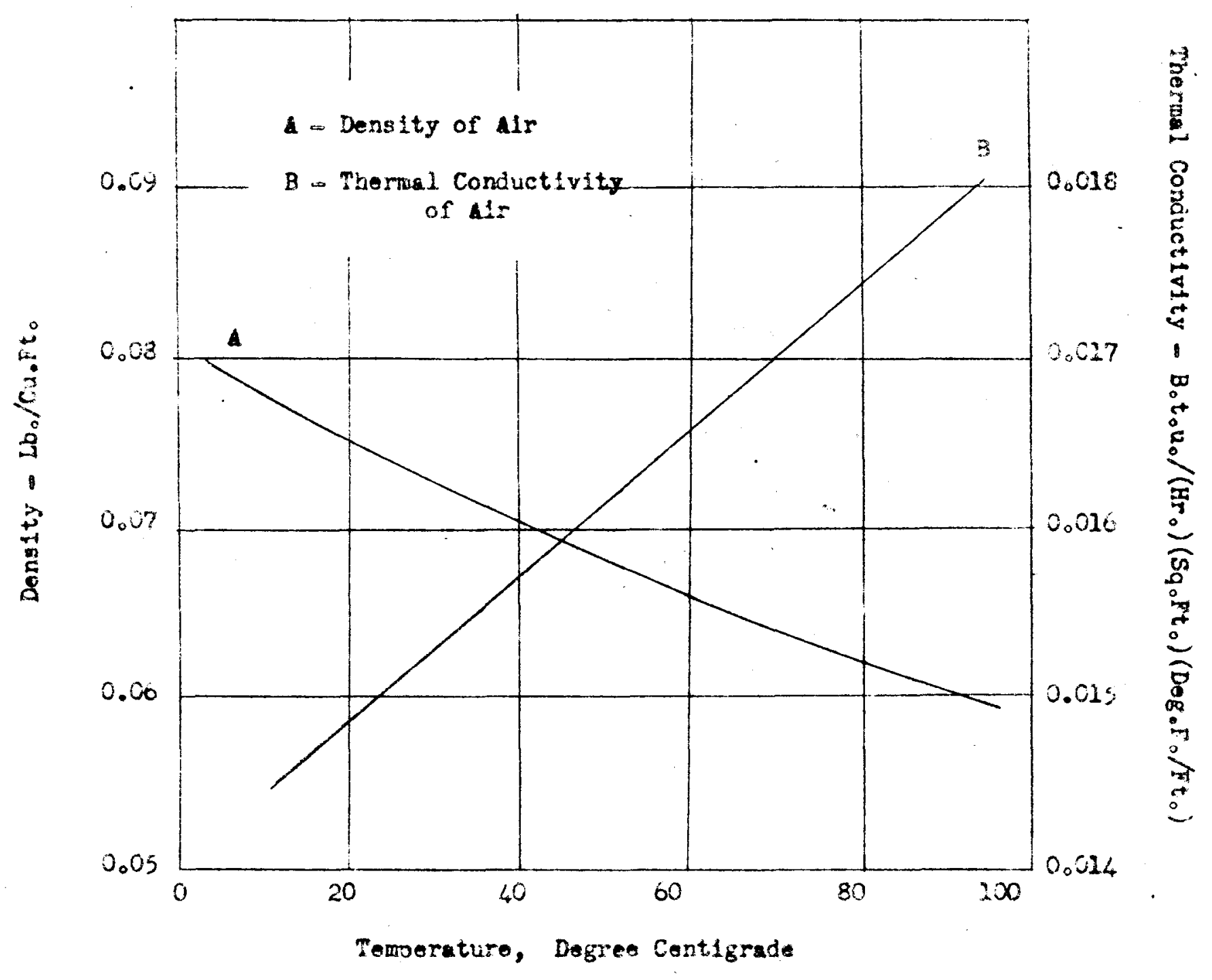

FIG。 6 - DENSITY ANO THERYAL CONDUCTIVITY OF AIR 


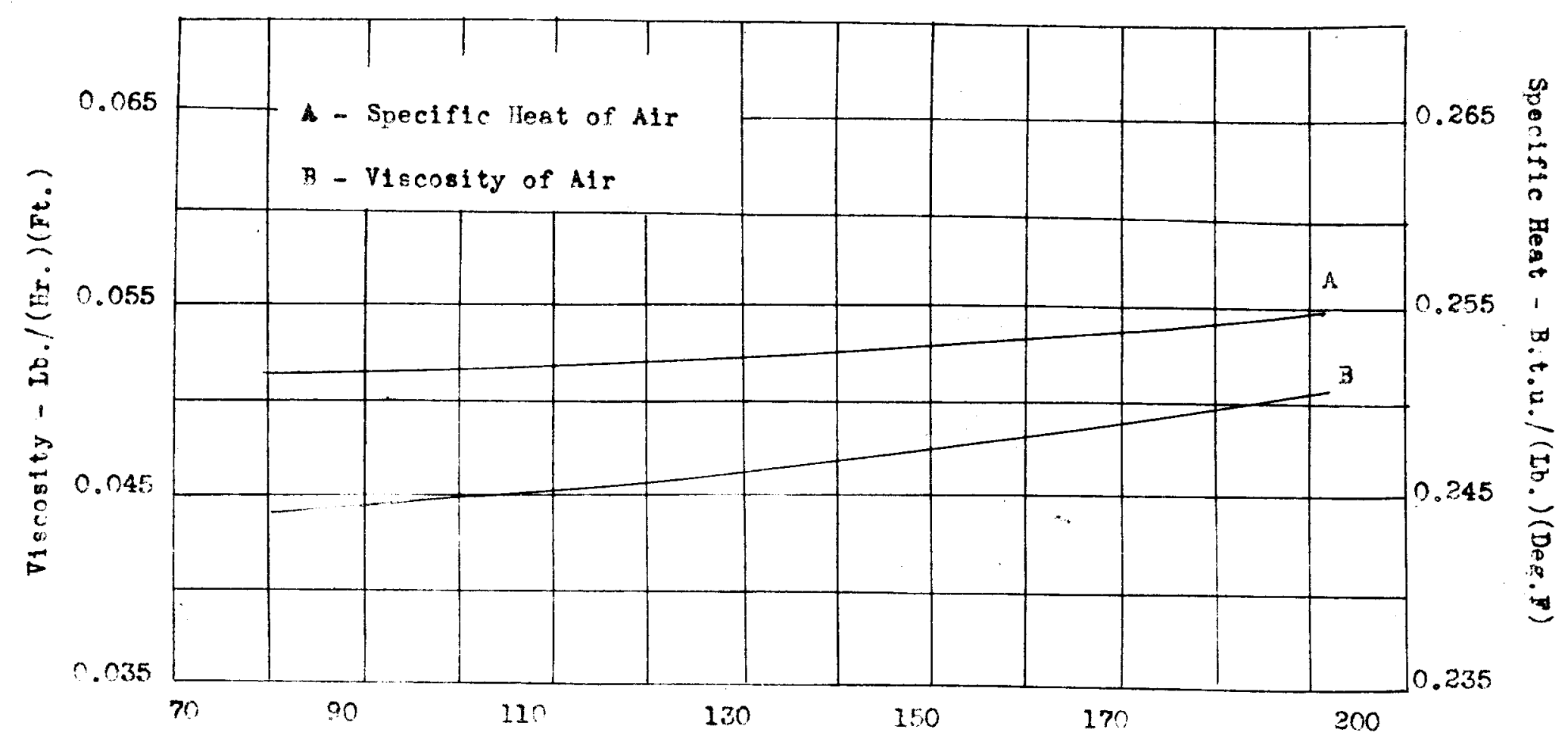

Temerature, Degree Fahrenheit

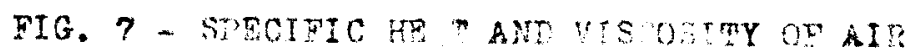


VIA 
The author, $\mathrm{N}$. P. Shah, was borm in December, 1923, in Ahmedabad, Bombay Province, India. He attended the Government Middle School from 1933 to 1935. He was graduated from the University of Bombay, Bombay, India, in 1940. Then he enrolled at the Gujarat College, (affiliated with the University of Bambay), Ahmedabad, and received his Bechelorg' degree in Chemistry from the University of Bombay, Bombay (India) in 1946 . In 1947 he was admitted for graduate studies in Chemical Angineering at the speed Scientific School of the University of Jouleville, and came to the United states of America in the foll of that year. He wes graduated in september, 1949, with the degree of Mastex of Chemieal Ingineering. 